\title{
How to Properly Read Your Irrigation Water Analysis for Turf and Landscape ${ }^{1}$
}

\author{
Marco Schiavon and Kimberly Moore ${ }^{2}$
}

Increasing population growth and urbanization have set limits on the amount of fresh water that can be utilized for outdoor irrigation. Many landscapers and turfgrass managers are forced to switch from fresh/canal water to other sources, such as reclaimed wastewater. Because water characteristics can affect soil and plant status, it is important to check water quality periodically. However, water analysis reports are often confusing and cumbersome to read, focused primarily on monitoring sodium $(\mathrm{Na})$ contents and little else. This paper will review several important water quality properties that need to be assessed when water samples are sent for analysis. This publication is intended for any homeowner or landscape manager dealing with bad water quality.

\section{pH}

The $\mathrm{pH}$ of irrigation water measures its acidity or basicity. $\mathrm{pH}$ ranges from 0 to 14 where $\mathrm{pH}$ of 7.0 denotes neutrality, while at $\mathrm{pH}<7.0$ water is acidic and at $\mathrm{pH}>7.0$ is basic

(Table 1). Desired values for irrigation water range from 6.5 to 8.4. While $\mathrm{pH}$ in irrigation water is seldom a problem, values outside the normal $\mathrm{pH}$ ranges could be an indicator of possible problems (e.g., too many bicarbonates dissolved in irrigation water). Abnormal acidity or basicity can influence nutrient availability, corrode irrigation equipment, and alter pesticide efficacy. Over time water $\mathrm{pH}$ can influence soil $\mathrm{pH}$.
Table 1. Irrigation water quality guidelines.

\begin{tabular}{|c|c|c|}
\hline Water Parameter & Unit & Desired Range \\
\hline $\mathrm{pH}$ & $1-14$ & $6.5-8.4$ \\
\hline $\mathrm{ECW}$ & $\mathrm{dS} / \mathrm{m}$ & $<0.75$ \\
\hline $\mathrm{TDS}$ & $\mathrm{ppm}$ & $<480$ \\
\hline $\mathrm{SAR}$ & - & $<6$ \\
\hline Hardness & $\mathrm{ppm}$ & $>50$ and $<150$ \\
\hline $\mathrm{HCO}_{3}^{-}$ & $\mathrm{ppm}$ & $<120$ \\
\hline $\mathrm{CO}_{3}^{2-}$ & $\mathrm{ppm}$ & $<15$ \\
\hline $\mathrm{Cl}$ & $\mathrm{ppm}$ & $<70$ \\
\hline $\mathrm{B}$ & $\mathrm{ppm}$ & $<0.5$ \\
\hline
\end{tabular}

\section{Salinity}

Salinity is defined as the concentration of salts that are dissolved in the irrigation water and is expressed as electrical conductivity $\left(\mathrm{EC}_{\mathrm{w}}\right)$, which is the ability to transmit electricity, shown as $\mathrm{dS} / \mathrm{m}$ (Table 1) or millimhos per centimeter (mmho/cm; Figure 1). Sometimes, it is also reported as total dissolved solids (TDS; expressed in ppm). Relationship between $\mathrm{EC}_{\mathrm{w}}$ and TDS is not linear, and this is why $\mathrm{EC}_{\mathrm{w}}$ is the preferred reported method over TDS. Generally,

$\mathrm{TDS}=\mathrm{EC}_{\mathrm{w}}{ }^{*} 640$ if $\mathrm{EC}_{\mathrm{w}}<5.0 \mathrm{dS} / \mathrm{m}$, and

$\mathrm{TDS}=\mathrm{ECw}^{\star} 750$ if $\mathrm{EC}_{\mathrm{w}}>5.0 \mathrm{dS} / \mathrm{m}$

When $\mathrm{EC}_{\mathrm{w}}>0.75$, water is considered high in salinity (US Regional Salinity Laboratory 1954). High salinity levels are common in recycled, tailored, and groundwater sources.

1. This document is ENH1352, one of a series of the Environmental Horticulture Department, UF/IFAS Extension. Original publication date December 2021. Visit the EDIS website at https://edis.ifas.ufl.edu for the currently supported version of this publication.

2. Marco Schiavon, assistant professor; and Kimberly Moore professor, Environmental Horticulture Department, UF/IFAS Ft. Lauderdale Research and Education Center, Davie, FL; UF/IFAS Extension, Gainesville, FL 32611.

The Institute of Food and Agricultural Sciences (IFAS) is an Equal Opportunity Institution authorized to provide research, educational information and other services

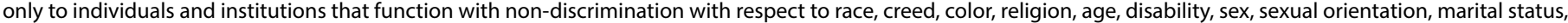

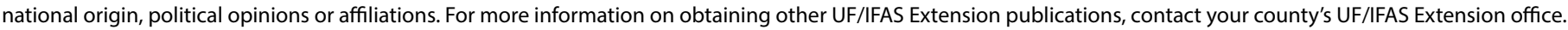
U.S. Department of Agriculture, UF/IFAS Extension Service, University of Florida, IFAS, Florida A \& M University Cooperative Extension Program, and Boards of County Commissioners Cooperating. Nick T. Place, dean for UF/IFAS Extension. 
When salinity levels increase, the osmotic potential of the soil water decreases, making water less available for plants, and potentially inducing physiological drought stress. Salinity thresholds for turfgrass species and ornamentals have been established in several greenhouse studies. However, when turfgrass and ornamentals are grown in fields, they are subjected to multiple stresses, including heat and drought, that exacerbate the salinity stressor.

Nevertheless, warm-season turfgrass species commonly grown in Florida are usually salt tolerant. The most salttolerant species grown in Florida is seashore paspalum (Paspalum vaginatum SW.), However, bermudagrass (Cynodon spp.), zoysiagrass (Zoysia spp.), and St. Augustinegrass (Stenotaphrum secundatum [Walt.] Kuntze) all tolerate high salinity levels in the water and soil.

One method to manage high salinity in irrigation water is to increase the volume of water applied. We increase the leaching fraction (amount of water applied) in order to push salts below the rootzone. The soil water content directly affects soil salinity. As water evaporates from the soil surface, more water rises from deeper depths depositing salts in the rootzone that need to be flushed.

\section{Sodium Adsorption Ratio}

When reading a water analysis report, there is a common misconception that sodium $(\mathrm{Na})$ is the most important or only salt that can create problems to plant and soil. The absolute concentration of $\mathrm{Na}$ in water has been given too much importance by landscape and turf managers. Specific foliar Na injury in turf is usually not visible due to high mowing frequency. Although the presence of $\mathrm{Na}$ in irrigation water in important, it is its concentration in relationship to calcium $(\mathrm{Ca})$ and magnesium $(\mathrm{Mg})$ that must be scrutinized. This relationship is called the Sodium Adsorption Ratio $\left(\mathrm{SAR}_{\mathrm{w}}\right)$ and is calculated as:

$\mathrm{SAR}=[\mathrm{Na}] /([\mathrm{Ca}]+[\mathrm{Mg}])^{1 / 2}$

Both $\mathrm{Ca}$ and $\mathrm{Mg}$ (primarily $\mathrm{Ca}$ ) are responsible for soil structure. When excessive $\mathrm{Na}$ is applied to the soil, it displaces Ca from soil colloid, causing soil deflocculation and consequent permeability problems. Concerns arise when $\mathrm{SAR}_{\mathrm{w}}>10$, especially in finer-textured soils (Table 1). Soil structure deterioration decreases soil permeability, making leaching of salts harder to achieve. Extremely coarse-textured soils, or golf greens that are constructed on pure sands, can be watered with higher SAR levels without serious concerns for deflocculation.
Management practices for correction of soil permeability hazard consist in amending soil with Ca-based products. Gypsum is often the preferred method to correct soil SAR due to its high availability and relatively low cost. Gypsum should be applied lightly and frequently as opposed to high rates all at once. For recommendations on when it is necessary to apply Ca for ameliorating soil and turfgrass health, refer to EDIS publication ENH1290, Calcium for Florida Turfgrasses (https://edis.ifas.ufl.edu/publication/EP554).

\section{Alkalinity}

The term alkalinity is often misused to refer to solutions that have a $\mathrm{pH}$ greater than 7 . However, alkalinity is the buffering capacity of water or its ability to neutralize acids. Buffering refers to how resistant a solution is to a change in $\mathrm{pH}$. In other words, the alkalinity of water is the total bicarbonates $\left(\mathrm{HCO}_{3}^{-}\right)$and carbonates $\left(\mathrm{CO}_{3}^{2-}\right)$ in the water that are available to neutralize acid or buffer against a change in $\mathrm{pH}$. We express alkalinity as milligrams per liter of calcium carbonate equivalents or as ppm bicarbonate per liter. Bicarbonate concentrations are considered low when lower than $120 \mathrm{ppm}$, moderate between 120 and $180 \mathrm{ppm}$, severe at 180-600 ppm, and very severe when higher than 600 ppm (Table 1).

Although high alkalinity does not pose a direct threat to plants, high presence of carbonates/bicarbonates dissolved in irrigation water could change soil $\mathrm{pH}$ or have an impact on fertilizers or other chemicals dissolved in the water. The carbonates and bicarbonates in water also could react with $\mathrm{Ca}$ and $\mathrm{Mg}$, forming insoluble calcium or magnesium products and impacting plant growth.

Correction of water with high alkalinity (carbonate/bicarbonate levels) can be obtained by acidification of water, typically using sulfuric acid that reacts with carbonates/ bicarbonates forming carbon dioxide. Injection of sulfuric acid into water to obtain acidification is a specialized practice, and it should be carried out after consulting with a specialized laboratory to decide if acidification is required and at what rates.

\section{Hardness}

Water hardness is the amount of dissolved calcium and magnesium. Both these cations are considered essential landscape plant nutrients; therefore "soft" water (below $50 \mathrm{ppm}$ ) is not ideal for landscape irrigation. The desired range of water hardness is between 50 and $150 \mathrm{ppm}$ (Table 1). Very hard water (above $300 \mathrm{ppm}$ ) could result in foliar deposits, damaged irrigation systems, and clogged pipes. 
Remediating water hardness using a softener (usually potassium) is recommended only when hardness is causing visible problems.

\section{Specific Ion Toxicity}

Specific ion toxicity is not a problem per se in turfgrass systems because turfgrass is mowed very often, but it may raise concerns for landscape plants, shrubs, and trees. Some ions, including $\mathrm{Cl}$ and $\mathrm{B}$, can be toxic to plants if accumulated in their leaves. Chloride is very common in irrigation water, and it can accumulate on leaves' tips and margins, inducing dehydration of plant calls, causing leaf firing (also called "chlorosis"). Boron is toxic at extremely low concentrations in irrigation water. Boron toxicity causes initial yellowing of leaf tissues followed by a dark necrosis on margins of older leaves.

\section{Summary}

There are many factors to consider when reading a water analysis report. Most water sources are acceptable to use to grow ornamental plants and turfgrass. However, it is a good practice to get your water analyzed when using a new source of water to better understand potential impacts.
The sample water analysis report from A\&L Southern Agricultural Laboratories, LLC compares water collected from a pond and from the Davie, Florida Wastewater Treatment facility (Figure 1). The $\mathrm{pH}$ for both water samples is within the acceptable guidelines listed in Table 1. The salinity is recorded as conductivity in this report, and $1 \mathrm{dS} / \mathrm{m}$ is the same as $1 \mathrm{mmhos} / \mathrm{cm}$. The salinity of the pond water is acceptable, but the wastewater salinity is higher than acceptable. The SAR for wastewater is also high and may cause problems. There are no carbonates in either water source, suggesting that the alkalinity is low. The pond water is considered soft, while the wastewater is considered very hard. The report confirms high levels of calcium and magnesium in the wastewater. After reading the report, we know that the pond water is acceptable to use. We also can use the wastewater but will want to monitor plant growth and be prepared to adjust as needed.

\section{References}

US Salinity Laboratory Staff. 1954. Diagnosis and Improvement of Saline and Alkali Soils. USDA Handb. 60. US Gov. Print. Office, Washington, DC.

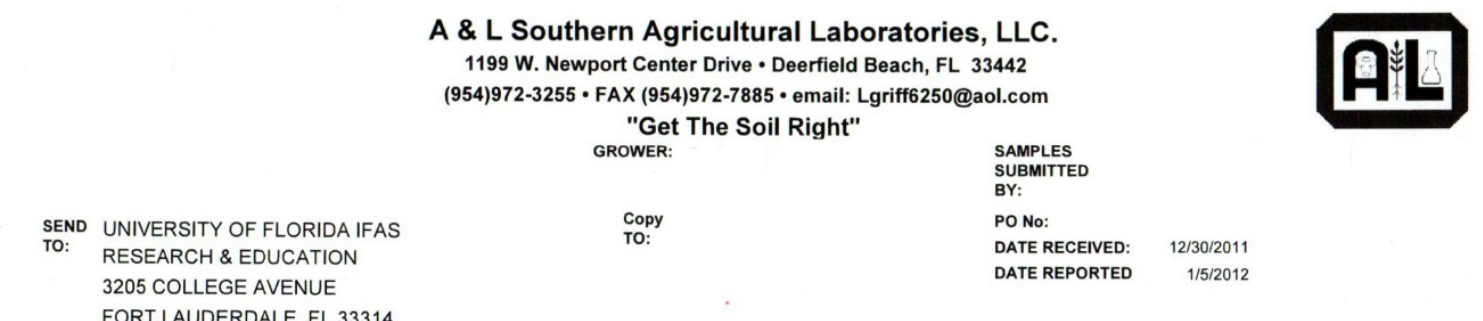

A \& L Southern Agricultural Laboratories, LLC. 1199 W. Newport Center Drive • Deerfield Beach, FL 33442 AX (954)972-7885 • email: Lgriff6250@aol.com SAMPLES FORT LAUDERDALE, FL 33314

WATER ANALYSIS REPORT

\begin{tabular}{|c|c|c|c|c|c|c|c|c|c|}
\hline $\begin{array}{l}\text { LAB NUMBER } \\
\text { SAMPLE ID }\end{array}$ & $\mathrm{pH}$ & $\begin{array}{c}\text { CONDUCTIVITY } \\
\text { mmhos/cm }\end{array}$ & $\begin{array}{c}\text { SODIUM } \\
\text { ppm }\end{array}$ & $\begin{array}{c}\text { POTASSIUM } \\
\text { ppm }\end{array}$ & $\begin{array}{l}\text { CALCIUM } \\
\text { ppm }\end{array}$ & $\begin{array}{l}\text { MAGNESIUM } \\
\text { ppm }\end{array}$ & $\begin{array}{c}\text { CARBONATE } \\
\text { ppm }\end{array}$ & $\begin{array}{l}\text { BICARBONATE } \\
\text { ppm }\end{array}$ & $\underset{\substack{\text { ppm } \\
\text { CHLORIDE }}}{ }$ \\
\hline Pond & $7.1 \mathrm{M}$ & $0.17 \mathrm{M}$ & $7 \mathrm{M}$ & 0 & 33 & $1 \mathrm{M}$ & 0 & & \\
\hline & $\begin{array}{c}\text { PHOSPHORUS } \\
\text { ppm }\end{array}$ & $\begin{array}{l}\mathrm{P} \text { as ORTHO } \\
\mathrm{pp}\end{array}$ & $\begin{array}{l}\text { HOSPHATE } \\
n\end{array}$ & $\begin{array}{l}\text { NITROGEN-N } \\
\text { ppm }\end{array}$ & $\begin{array}{l}\text { NITRATE NO3 } \\
\text { ppm }\end{array}$ & $\underset{\mathrm{ppm}}{\mathrm{NH4-N}}$ & $\begin{array}{l}\text { UREA } \\
\text { ppm }\end{array}$ & $\begin{array}{c}\text { SULFATE SO4 } \\
\text { ppm }\end{array}$ & $\begin{array}{c}\text { BORON } \\
\text { ppm }\end{array}$ \\
\hline & $\begin{array}{c}\text { IRON } \\
\text { ppm }\end{array}$ & $\begin{array}{c}\text { FI } \\
\text { FLUORIDE ppm }\end{array}$ & $\begin{array}{l}\text { MANGANESE } \\
\text { ppm }\end{array}$ & $\begin{array}{l}\text { ZINC } \\
\text { ppm }\end{array}$ & $\begin{array}{c}\text { COPPER } \\
\text { ppm }\end{array}$ & \multicolumn{2}{|c|}{$\begin{array}{c}\text { TOTAL DISSOLVED SOLIDS } \\
\text { ppm }\end{array}$} & \multicolumn{2}{|c|}{$\begin{array}{l}\text { SODIUM ABSORPTION } \\
\text { RATIO }\end{array}$} \\
\hline & & & & & & \multicolumn{2}{|l|}{$108.80 \mathrm{M}$} & \multirow{2}{*}{\multicolumn{2}{|c|}{$\begin{array}{c}\text { ALKALINITY } \\
\text { ppm as CaCO3 }\end{array}$}} \\
\hline & $\begin{array}{c}\text { MOLYBDENUM } \\
\text { ppm }\end{array}$ & COLIFORM & $\begin{array}{l}\text { Colonies } \\
\text { FECAL COL }\end{array}$ & $\begin{array}{l}\text { er } 100 \mathrm{ml} \\
\text { OTHER }\end{array}$ & ACTERIA & \multicolumn{2}{|c|}{ HARDNESS } & & \\
\hline \multirow[t]{2}{*}{ No. 2 Waste } & $7.0 \mathrm{M}$ & $1.93 \mathrm{H}$ & $251 \mathrm{VH}$ & 0 & 123 & $26 \mathrm{H}$ & 0 & $\begin{array}{l}\text { BICARBONATE } \\
\text { ppm }\end{array}$ & \\
\hline & $\begin{array}{c}\text { PHOSPHORUS } \\
\text { ppm }\end{array}$ & \multicolumn{2}{|c|}{$\begin{array}{l}\text { Pas ORTHO PHOSPHATE } \\
\mathrm{ppm}\end{array}$} & $\begin{array}{l}\text { NITROGEN-N } \\
\text { ppm }\end{array}$ & $\begin{array}{c}\text { NITRATE NO3 } \\
\text { ppm }\end{array}$ & $\underset{\mathrm{ppm}}{\mathrm{NH4-N}}$ & $\begin{array}{l}\text { UREA } \\
\text { ppm }\end{array}$ & $\begin{array}{c}\text { SULFATE SO4 } \\
\text { ppm }\end{array}$ & $\begin{array}{c}\text { BORON } \\
\text { ppm }\end{array}$ \\
\hline 1 & $\begin{array}{l}\text { IRON } \\
\text { ppm }\end{array}$ & $\begin{array}{c}\text { FI } \\
\text { FLUORIDE ppm }\end{array}$ & $\begin{array}{c}\text { MANGANESE } \\
\text { ppm }\end{array}$ & $\begin{array}{l}\text { ZINC } \\
\text { ppm }\end{array}$ & $\begin{array}{c}\text { COPPER } \\
\text { ppm }\end{array}$ & \multicolumn{2}{|c|}{$\begin{array}{c}\text { TOTAL DISSOLVED SOLIDS } \\
\text { ppm }\end{array}$} & \multicolumn{2}{|c|}{$\begin{array}{l}\text { SODIUM ABSORPTION } \\
\text { RATIO }\end{array}$} \\
\hline
\end{tabular}

CODE TO RATING - Very Low (VL - Low (L) - Medium (M) - Very High (VH) Too Numerous to Count (TNTC) Our reports and letters are for the exclusive and confidential use of our clients, and may not be reproduced whole or in part, nor may any reference be made success is neither warranted nor implied. Apply fertilizers carefully to avoid groundwater pollution.

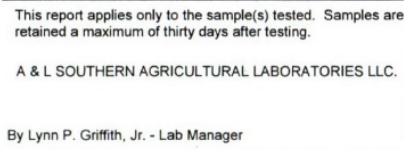

By Lynn P. Grittith, J.. Lab Manager

Figure 1. Water analysis report comparing water collected from a pond and water collected from the Davie, Florida Wastewater Treatment Facility. Samples were collected in December 2011, and analysis was conducted at A \& L Southern Agricultural Laboratories, LLC. 